The allocation of financial risks during the life cycle in individual and collective DC pension contracts

Ilja Boelaars

Ryanne Cox

Marcel Lever

Roel Mehlkopf 



\title{
The allocation of financial risks during the life cycle in individual and collective DC pension contracts
}

\author{
Ilja Boelaars ${ }^{a}$ \\ Ryanne Cox ${ }^{b}$ \\ Marcel Lever ${ }^{c}$ \\ Roel Mehlkopf ${ }^{d}$
}

\section{December 2015}

\begin{abstract}
This paper measures how financial shocks - equity market, interest rate or inflation shocks - affect different generations of participants in pension schemes. We show that an individual scheme, by using a life cycle investment strategy, can largely replicate the allocation of traded risks across generations of a collective pension scheme that gradually adjusts pensions after financial shocks. Collective schemes can shift financial risk to generations that will participate in the future, whereas individual accounts cannot. In the current institutional setting this shift of traded risk in collective contracts to future generations is limited. Collective pension schemes are able to reallocate nontraded risks among the participants to obtain a more efficient distribution of risk across generations. In schemes with individual accounts, risk sharing is limited to risks traded on financial markets.
\end{abstract}

Keywords: intergenerational risk sharing, pre-funded pension schemes, impulse-response analysis

JEL Code(s): D91, G11, G23

\footnotetext{
${ }^{a}$ University of Chicago

${ }^{b} D N B$

${ }^{C}$ CPB Netherlands Bureau for Economic Policy Analysis

${ }^{d}$ DNB and Netspar
}

\footnotetext{
* Earlier versions of this paper circulated under the title "Risk Sharing in Funded Pension Schemes" and "What is the value of "collective" in collective DC?". We thank Albert van der Horst, Thomas Michielsen, Theo Nijman, Ed Westerhout and seminar participants at AFM, Cardano, CPB, DNB, Ortec Finance, the Dutch Ministries of Finance and of Social Affairs and Employment, the Netspar 2020 working group, and the conference "Pensions in Europe" at Bruegel in Brussels in December 2013 for helpful comments and suggestions. Financial support from Netspar and MOPACT is gratefully acknowledged. MOPACT has received funding from the European Union's Seventh Framework Programme for research, technological development and demonstration under grant agreement no. 320333.
} 


\section{Introduction}

Many occupational pension schemes around the world have shifted from guaranteed, defined benefits (DB) towards defined contributions (DC). The transition from DB to DC schemes is the result of a withdrawal of employers as risk sponsors. Many companies no longer wish to underwrite the risks of their pension funds, as these risks are too large in comparison to their core business. In DC pension contracts, all financial and demographic risks are borne by the plan participants.

The design of these DC plans can take different forms. In individual defined contribution (IDC) schemes participants save and invest in an individual account on the basis of traded financial assets. In collective defined contribution (CDC) schemes, in contrast, assets are collectively owned by the participants. CDC contracts can smooth the impact of (financial) shocks over time by using its financial buffer to share the impact of the shock with current and possibly even future participants of the contract. ${ }^{1}$ Examples of IDC contracts can be found in private sector plans in the US and the UK, and the individual-account pension system in Chile. Examples of CDC contracts are the sector-wide pension schemes in the Netherlands. CDC contracts are also part of the debate in the UK, where the government is seeking to enable pension schemes that offer collective benefits as an alternative to traditional IDC contracts. ${ }^{2}$ Also in public-sector pension schemes in the United States risk sharing is being considered as a way to reduce the costs of these schemes, see e.g. Novy-Marx and Rauh (2012).

The existing literature on risk sharing in occupational pension funds, e.g. Teulings and De Vries (2006) and Gollier (2008), reports large ex ante welfare gains associated with sharing asset risk between non-overlapping generations in funded pension schemes. In the absence of commitment problems, it is optimal to diversify risk over as many generations as possible, such that each generation is affected as little as possible. In practice, however, it is unlikely that this solution is sustainable. When young workers face substantial negative buffers on entry into a pension scheme, they may simply seek employment elsewhere. Discontinuity risks provide a rationale for regulation that limits the possibilities for risk sharing between non-overlapping generations in occupational pension schemes. Whereas intergenerational risk sharing can improve welfare for all generations from an ex ante perspective, some generations are worse off ad interim. As a result, the first-best risk sharing solution is vulnerable to discontinuity risk, see e.g. Bovenberg and Mehlkopf (2014). In real-life occupational pension schemes the possibilities for risk sharing between non-overlapping generations are therefore limited.

This paper measures how CDC and IDC pension contracts allocate traded and non-traded risks to generations of participants and evaluates the differences. The impact of financial shocks on the consumption of each generation is visualized using an impulse-response analysis. We restrict the analysis to financial risks (equity market, interest rate and inflation risk) and do not include

\footnotetext{
${ }^{1}$ Risk sharing with future generations, i.e. participants that have not entered the pension plan yet, is more feasible with mandatory participation in the pension plan. Without mandatory participation, new employees may be unwilling to join when the plan is underfunded.

${ }^{2}$ The Private Pension Bill announced in the Queen's speech (2014) during the state opening of parliament would enable 'collective schemes' that pool risk between members and potentially allow for greater stability around pension outcomes. A public consultation by the Department for Work and Pensions (2013) outlines proposals for a new regulatory framework for future pension provision.
} 
demographic risks (longevity and fertility risk). ${ }^{3}$ The difference between individual and collective contracts here refers solely to the ownership of pension assets. The analysis abstracts from other possible differences between collective and individual contracts, with respect to mandatory participation, costs of marketing or asset management, options for choice, transparency or completeness of the contract.

The first finding of this paper is that the reallocation of traded risks from the elderly to young and future generations in CDC schemes is in practice relatively small, as recovery periods are short due to solvency rules. Besides, adjustment of pension contributions has become less effective as a result of increased labor market mobility. ${ }^{4}$ With a 10 -year recovery period ${ }^{5}$, which corresponds more or less with Dutch solvency rules, approximately $96 \%$ of the risk is borne by the generations that currently participate in the scheme and only $4 \%$ by future participants. In fact, we find that an IDC scheme, by using a life cycle investment strategy, can largely replicate the allocation of traded risks across generations of a CDC scheme. ${ }^{6}$ The welfare gain of sharing $4 \%$ stock market risk with future generations is limited compared to a first-best setting, where it is 50\% (see Bovenberg and Mehlkopf, 2014). In a theoretical first-best setting, the ex ante welfare gain associated with risk sharing is in the order of magnitude of $12 \%{ }^{7}$ Our results indicate that in the Dutch institutional setting the welfare gain of risk sharing with future generations is much smaller: in the order of $1 \%{ }^{8}$ Hence, the theoretical welfare gains associated with risk sharing between non-overlapping generations are not representative for real-world Dutch collective contracts. The study by Westerhout, Bonenkamp and Broer (2014) reaches a similar conclusion.

\footnotetext{
${ }^{3}$ We assume that all pension contracts pay lifetime benefits. In the IDC scheme, in which participants own claims on traded assets, this can be organized by collectively pooling longevity risk. The assets in the individual accounts of members who die are redistributed to the surviving participants.

${ }^{4}$ Gollier (2008) also includes an analysis of risk sharing with a solvency constraint. However, the solvency constraint in his study is rather weak as it requires the pension fund to be able to return the pension contributions (excluding interest gains) that participants have paid in the past. In real life settings, however, solvency rules are typically aimed at preventing a funding deficit and thus effectively require pension funds to be able to return pension contributions including interest gains.

${ }^{5}$ This is in line with the revised Financial Assessment Framework (Financieel Toetsingskader/FTK) that Dutch occupational pension funds are subject to from 1 January 2015. In practice, the recovery process of Dutch pension funds can take longer than 10 years, because the solvency framework does not impose a strict deadline for recovery, but instead imposes an asymptotic recovery process that is similar to a 'rolling window' mechanism (see Appendix B).

${ }^{6}$ We allow for so-called "variable annuities" in the IDC contracts, so the participant may be exposed to investment risk in the decumulation phase. These variable annuities are currently not allowed in Dutch individual pension contracts. However, regulatory changes to facilitate variable annuities for Dutch DC pensions are currently under consideration.

${ }^{7}$ In a typical theoretical setting, the welfare gain associated with sharing stock market risk with nonoverlapping generations equals $1 / 2$ times the investment horizon of a generation multiplied with the square of the Sharpe ratio divided by the parameter of relative risk aversion (see Bovenberg and Mehlkopf, 2014). If the investment horizon of a generation is 30 years, the Sharpe ratio is $20 \%$ and the parameter of relative risk aversion is 5 , then the welfare gain associated with risk sharing equals $1 / 2 * 30 * 0.2^{2} / 5=12 \%$.

${ }^{8}$ If we assume a linear relationship between the size of risk sharing and welfare gains, the $4 \%$ of risk sharing with future generations in the Dutch institutional setting would correspond with a welfare gain of approximately $(4 \% / 50 \%) * 12 \% \approx 1 \%$. On average occupational pensions in the Netherlands amount to roughly half of total retirement income, the remainder coming from the pay-as-you-go first-pillar pension. As the relationship between the size of risk sharing transfers and welfare gains is not linear, we estimate that the welfare gain associated with risk sharing with future generations in occupational pension schemes in the Netherlands is between $1 / 2 \%$ and $1 \%$.
} 
The second finding is that CDC schemes protect young participants to declines in the nominal interest rate, whereas IDC schemes that only invest in equity at young ages do not. This has been highly relevant in the last couple of years, when the interest rate decreased substantially. Hedging about half of the interest risk combined with the gradual adjustment after shocks seems sufficient to protect the elderly in CDC schemes against excessive (downside) interest risk.

The third finding is that collective contracts are able to reallocate non-traded risks, such as inflation risk, from the elderly to younger generations. We show that $C D C$ contracts can in principle cut the exposure of occupational pensions to inflation risk of elderly participants roughly in half. The other half of the inflation risk of the elderly is reallocated to working participants, who may be better able to bear this risk since their human capital provides a natural hedge against inflation risk (assuming that wages are correlated with inflation). ${ }^{9}$ This feature of $C D C$ contracts cannot be replicated in an IDC scheme with individual accounts if inflation risk is not (widely) traded. The ability of CDC contracts to reallocate inflation risk across generations is therefore less relevant for the US and the UK, where there is a liquid and transparent market for inflation risk. Nevertheless, this finding is relevant in countries with a less liquid market for inflation risk, such as the Euro area. In practice, the possibilities for sharing inflation risk between generations are rather limited in Dutch CDC contracts, as the costs of inflation are not included in the liabilities of the funds.

After the first version of this paper, also Bouwman and Kocken (2014) reproduced the distribution of stock market risk across age-groups. Two other follow-up studies adopted a stochastic approach, see Lever and Michielsen (2015) and Chen et al (2014). The results in our paper and these three related papers are summarized in the short note by Boelaars et al. (2014).

The structure of this paper is as follows. Section 2 summarizes earlier literature on the allocation of risk during the life cycle and the benefits of intergenerational risk sharing in collective pension contracts. Section 3 describes the impulse-response methodology and specifies the design of the IDC and $C D C$ contracts that we compare. Section 4 presents the results on the allocation of financial risks during the life cycle in individual and collective DC pension contracts. Section 5 concludes. Appendix A provides some background information on Dutch occupational pension contracts. Appendix B provides a robustness check of the results.

\section{Earlier literature on the allocation of risk during the life cycle in pension contracts}

According to the theory of general equilibrium of Arrow and Debreu (1954), the allocation of risk in financial markets is Pareto efficient if markets are complete. Hence, a collective pension scheme (or more generally speaking: a social planner) can improve welfare only if it enables risk trading that is not possible in financial markets. We distinguish two types of market incompleteness that can be addressed by a collective pension scheme. First, in conventional financial markets current generations are not able to trade with unborn generations, because these generations are not present in financial markets at the same time. ${ }^{10}$ Second, certain risk factors are not (widely) traded

\footnotetext{
${ }^{9}$ Many governments already offer inflation-linked public pension benefits to retirees, financed through contributions paid by workers.

${ }^{10}$ Early contributions by Diamond (1977), Merton (1983), and Gordon and Varian (1988) already made this point. More recent contributions include Allen and Gale (1997), Shiller (1999, 2003), Smetters (2006), Teulings
} 
in financial markets. We discuss both types of market incompleteness below and analyse the economic benefits of risk sharing in collective pension contracts.

\section{Traded risk factors}

Financial markets only allow trade between generations that are present in financial markets at the same time. Even if all risk factors are traded, current generations cannot trade with unborn generations, who are not active in financial markets yet. This 'biological trading constraint' can cause the allocation of risk across generations in financial markets to be inefficient, because unborn generations are unable to share in current risks.

A collective pension scheme allows participants to share risks with future generations, if there is no uncertainty on the inflow of new participants and the continuity of the contract. By sharing risk (or smoothing shocks) over a longer period of time, collective pension funds facilitate risk trading between non-overlapping generations. This enables future generations to bear financial market risk before they start working and earn more risk premium than they could do in an individual pension contract; see Teulings and De Vries (2006).

Not only future generations, but also young generations may have restricted access to financial markets. Adverse selection, moral hazard, and limited liability of human capital typically preclude borrowing against future labor income; see e.g. Constantinides et al. (2002). Financial institutions cannot use human capital as collateral to ensure that the loan is paid back. With borrowing constraints, agents must get all their risk exposure from positive financial capital. The borrowing constraint may be binding for young generations, who have not accumulated substantial financial wealth.

The theory of life cycle investing (see e.g. Bodie, Merton and Samuelson, 1992) finds that it can be optimal for young generations to have a higher exposure to financial market risk than corresponds with their financial assets. For someone who has just entered the labor market, and consequently has little financial relative to human capital, the optimal allocation to equity market risk is likely to exceed the individual's financial capital. ${ }^{11}$ Unless they are able to borrow against their human capital, young generations are therefore unable to invest the optimal share of their capital in the stock market and earn the corresponding equity risk premium. By pooling human capital of young (and future) generations with financial capital of the older generations in a collective pension fund, the young are able to participate in the stock market and earn more risk premium than they would be able to do in an individual pension contract.

We conclude that collective pension contracts allow for sharing traded risk factors, such as stock market risk, with future generations of participants and lift the borrowing constraints of younger generations.

and De Vries (2006), Bohn (2006, 2009, 2012), Ball and Mankiw (2007), Campbell and Nosbusch (2007), Gollier (2008) and Cui et al. (2011). An overview of the literature on intergenerational risk sharing in funded pension schemes is provided in Bovenberg and Mehlkopf (2014).

${ }^{11}$ This is typically the case if one assumes that human capital is riskless. If human capital is highly correlated with investment returns, it can be optimal to invest a low (or even negative) proportion of financial wealth in risky assets when young, see Benzoni et al. (2007). 


\section{Non-traded risk factors}

A collective pension scheme may also enhance welfare, if it enables participants to trade risks that are not traded in financial markets. For example, inflation risk is non-traded in most countries except the US and the UK. The depth of the market for inflation-linked bonds in the Euro area amounts to approximately $€ 350$ billion, ${ }^{12}$ whereas accumulated pension assets in the Netherlands alone represent a value of more than $€ 1$ trillion. ${ }^{13}$ In the absence of a liquid market for inflation-linked instruments, pension contracts that aim to revalue participants' entitlements for inflation will have difficulty building a matching portfolio.

In a collective pension fund that shares inflation risk, young and future participants can earn an inflation risk premium in exchange for compensating elderly participants for unexpected inflation. Similarly, a collective contract allows elderly to maintain exposure to productivity growth by linking pension benefits to wage inflation (see Beetsma and Bovenberg, 2009). Finally, a collective pension scheme can reallocate macro-longevity risk from older to younger generations. Macro-longevity risk refers to uncertain development in future average mortality rates of a pool of individuals. Collective contracts enable reallocation of non-traded risk, such as inflation risk, from the elderly to young and future generations, thereby complementing financial markets. ${ }^{14}$

\section{Methodology}

This section describes the methodology to determine the allocation of financial risks during the life cycle. It specifies the IDC and CDC pension schemes that are compared in our analysis.

\section{Impulse-response analysis}

We apply a so-called "impulse-response analysis" in a pension model to measure the impact of a single economic shock on the income (or consumption) of different generations of participants. This allows us to compare the impact of shocks across generations in IDC and CDC contracts. The consumption effect for a particular generation that results from an economic shock is measured as the percentage change in the purchasing power of retirement income during the retirement period as a whole. ${ }^{15}$

The IDC and CDC contracts are designed such that the exposure to economic shocks aggregated across all generations is set equal. For example, the share that is invested in equity at the aggregate

\footnotetext{
${ }^{12}$ The market size for euro-denominated inflation-linked products amounted to $€ 334$ bn on 30 April 2012; see Barclays (2012).

${ }^{13}$ In addition, if a Dutch pension fund invests in French or Greek inflation-linked bonds to hedge the inflation risk on its accrued benefits, the inflation protection is imperfect as inflation rates differ between countries.

${ }^{14}$ Inflation risk can also be made more tradable by the issue of inflation-linked bonds by governments, as happened in the UK (Index-Linked Gilts) and the US (Treasury Inflation-Protected Securities, or TIPS). The same is, in theory, possible for longevity bonds.

${ }^{15}$ Most contracts that we consider feature a constant contribution rate so that consumption during the accumulation period is unaffected by the design of the pension contract. This allows us to restrict our attention to consumption effects during retirement. We also examine a collective contract wherein the contribution rate is temporarily higher or lower than the actuarially fair rate to enhance recovering of the solvency rate. We assume that the difference between the actual and actuarially fair contributions is saved or borrowed by the participant and that the resulting consumption effect occurs during retirement. Hence, also in this case we are able to restrict our focus to the retirement period when evaluating consumption effects.
} 
level is the same in both contracts. The contracts differ only in the way the equity risk is distributed across generations. Furthermore, all contracts that we consider are ex ante actuarially fair and not distorted by redistributive effects.

Impulse-response analysis does not account for interaction of economic shocks across time. This limitation of our methodology is not a major drawback for the determination of the allocation of shocks. Dutch collective pension contracts are designed in such a way that the impact of a current shock is roughly independent of the (size and sign) of shocks that occurred in the past. The 10-year recovery period in the Dutch regulatory framework is effectively a 'rolling window'. All shocks are distributed across time and generation in a similar way, regardless of the financial position of a pension fund. Hence, an analysis of a single shock is sufficient to measure the allocation of risk across generations in Dutch CDC schemes. ${ }^{16}$

Although the analysis in this paper is restricted to single shocks, the method can provide some insight in the extent to which pension contracts are able to exploit correlations of shocks across time. For example, if the impulse-response analysis points out that a collective scheme is able to distribute risks across a larger number of generations (e.g. not only current but also future generations) in comparison to an individual scheme, then a collective scheme is better able to exploit the benefits of correlations of shocks across time.

\section{Pension model}

The analysis focuses on financial risks and abstracts from demographic risk (longevity and fertility risk). The life cycle and labor participation of generations are assumed to be deterministic: all generations start working at 25 , retire at 65 and live up to age 85 . All generations that participate in the pension scheme are equal in size. Wages are deterministic in real terms so that human capital provides a hedge against inflation risk in our calculations. Real aggregate wages (aggregated across all age groups) grow at a rate of 1 percent annually. In addition, we assume that the wage profile rises during the life cycle with 1 percent per year of additional experience (age). Wages are exogenous, thus pension contributions, that are supposed to be paid by the employee, reduce current incomes (after pension contributions, but before income taxes) one for one. There are no private savings.

We use four types of economic shocks:

- a permanent shock in stock prices;

- a permanent shock to the (both nominal and real) interest rate;

- a permanent shock in the price level, without affecting future nominal and real interest rates;

- a permanent shock in inflation and in nominal interest rates, without affecting real interest rates.

\footnotetext{
${ }^{16}$ In recent years there have been proposals for including a 'smoothing reserve' in the design of Dutch pension schemes. This reserve accumulates additional wealth during good economic times and acts as a buffer against future losses. It effectively means that positive economic shocks during good economic times are spread over a longer horizon. Hence, the economic effects of such a reserve during good economic times can be measured by analyzing a longer recovery period. Our robustness analysis therefore includes a recovery period of 30 years instead of 10 years.
} 
The shocks occur in 2015, thereby potentially affecting the consumption patterns of generations that are in 2015 retired (cohorts born between 1931 and 1950) or working (cohorts born between 1951 and 1990). In collective contracts that use a recovery period to absorb financial shocks also generations that have not yet started working (cohorts born after 1990) are affected. The model abstracts from differences between short-term and long-term interest rates: both the nominal and the real interest rate term structures are flat.

The pension fund in our model can invest in stocks and nominal bonds. Pensioners can choose either nominal annuities offering a fixed payoff or variable annuities offering a stochastic payoff that may fluctuate with stock market risk and/or nominal interest rate risk. Notice that the annuities can simply be considered as investment strategies that are based on bonds and stocks, since our model abstracts from longevity risk. Participants can expose or insure themselves against two financial risk factors: stock market risk and interest rate risk. The economy has two additional risk factors, namely unexpected and expected inflation risk. We assume that the financial market is incomplete, as these inflation risks are not traded. We abstract from transaction costs.

\section{Design of IDC contracts}

In the IDC schemes participants save and invest in individual accounts during the accumulation phase and convert their wealth into an annuity at retirement age. During the accumulation phase, savings can be invested in stocks and nominal bonds. At retirement, participants either convert their wealth into a nominal or a variable annuity. A variable annuity that is linked to stock market risk allows participants to continue to earn the risk premium in financial markets after retirement. ${ }^{17}$

\section{Table 1: Design of IDC contracts}

\section{IDC benchmark}

Constant contribution rate

Life cycle asset mix during accumulation phase with share in stocks equal to $100 \%$ between ages 25 and 35 , then linearly decreasing from $100 \%$ to $30 \%$ between ages 35 and 65 . Remaining fraction of wealth is invested in nominal bonds.

Variable annuity during retirement period with exposure to stock market risk linearly decreasing from $30 \%$ to $0 \%$ between ages 65 and 85 . The remaining exposure is based on bond returns.

The duration of bonds is set equal to the number of years until average retirement consumption. That is, during the working period the duration of bonds is equal to $(85+65) / 2$ minus the current age and after retirement it is equal to ( $85+$ current age) $/ 2$. The duration of bonds is capped at 30 years because the market for bonds with durations higher than 30 years is not very liquid.

\section{IDC variation}

No life cycle profile. The exposure to stocks is equal to $49 \%$ (the weighted average across all ages of the exposure to stocks in the benchmark design).

\footnotetext{
${ }^{17}$ If risk aversion is finite, it is typically optimal to invest some share of wealth in risky assets after retirement; see Bovenberg et al. (2007).
} 
The benchmark design of the IDC scheme features a life cycle investment profile, where the fraction of wealth invested in stocks decreases during both the accumulation phase as well as the decumulation phase, see table 1 . The design of the lifecycle resembles the patterns in the literature, see e.g. Cocco et al. (2005), Bovenberg et al. (2007) and Blake et al. (2014), but we don't claim optimality. The exposure to stocks at young ages is capped at $100 \%$ as a result of borrowing constraints on individual investors. The duration of bond holdings decreases with age in correspondence to the remaining lifespan of the participant (and hence with the participant's hedging demand for interest rate risk). Figure 1 provides an illustration of the life cycle portfolio strategy in the IDC contract.

Table 1 also specifies a variation that differs on a single aspect from the benchmark design. The variation features a constant exposure to stock market risk during the entire life cycle instead of a decreasing exposure. The exposure to stock market risk is equal to 49 percent: the weighted average across all ages of the exposure to stocks in the benchmark design.

Figure 1 Fraction invested in stocks (left) and duration of bonds (right) during the life cycle in IDC
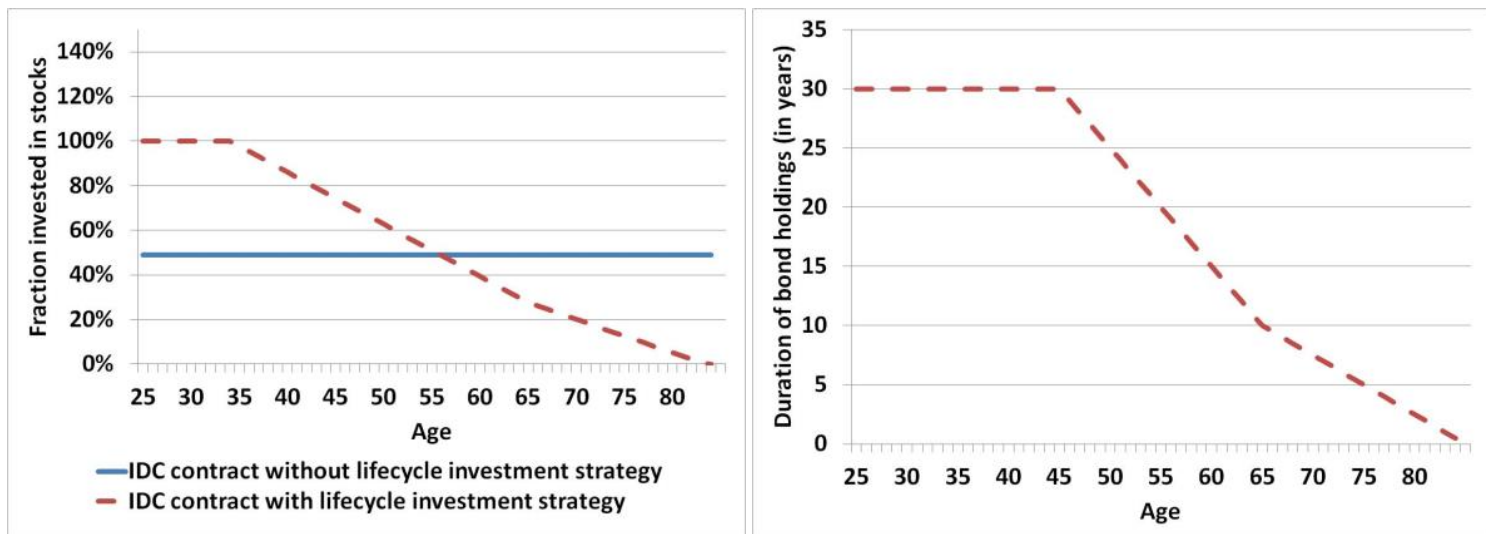

\section{Design of CDC contracts}

The collective pension scheme holds a single, collective pool of assets on behalf of its participants, invested in stocks and nominal bonds. Participants accrue annuity units that may be increased when asset returns perform well, but may be cut if investments perform below expectations. The balance sheet risk of the collective pension fund is distributed across time (and hence generations) on the basis of a recovery period. Hence, unexpected financial returns on investments are allocated to the fund's participants in series of annual adjustments of annuity units during a recovery period.

The collective contracts are actuarially fair in the sense that at all times and for all individual participants, the contributions pledged into the scheme match with the market value of the accrued pension entitlements. This is accomplished by designing collective contracts (1) that are actuarially fair if the fund would fully invest in the risk-free rate and (2) by applying linear policy rules so that risk taking by the pension fund does not affect the ex ante market value of the accrued entitlements. $^{18}$

\footnotetext{
${ }^{18}$ In a linear contract the value of accrued pensions is unaffected by changes in the investment strategy of the pension fund, as the change in equity risk is distributed in the same way as the resulting change in risk premium. See Bovenberg, Nijman and Werker (2012) and Lever, Mehlkopf and Van Ewijk (2012).
} 
In the benchmark design of the collective contract, the pension fund applies a 10-year recovery period, see table 2. It invests 49 percent of its collective assets in stocks and the remaining 51 percent in nominal bonds. This fraction of 49 percent invested in stocks is chosen in such a way that the collective fund invests the same amount of assets in stocks as all the individual investors together in the benchmark IDC contract. Hence, the aggregate loss that results from an equity shock is the same in the benchmark CDC contract and the benchmark IDC contract. The two contracts only differ in the distribution of equity risk across different generations. Notice that in the benchmark collective contract, entitlements are not guaranteed. The pension fund does not hedge its liabilities with a matching portfolio of assets. The resulting mismatch risk on the balance sheet of the pension fund is distributed across time (and generations) through the 10-year recovery period. In the benchmark collective contract, the contribution rate is constant and is set at the same level as in the individual contract. The CDC schemes roughly correspond to Dutch collective pension contracts, that are described in Appendix A.

\section{Table 2: Design of CDC contracts}

\section{CDC benchmark}

Constant contribution rate (same as in IDC contract).

10-year recovery period to distribute financial shocks on the balance sheet of the collective scheme (and generations).

Constant fraction of $49 \%$ of collective assets invested in stocks, close to the average of Dutch pension funds, and matching the stock market risk of the IDC contract aggregated across all generations. The remaining $51 \%$ of collective assets is invested in bonds.

The duration of bonds in the CDC contract is set such that it hedges $43 \%$ of the nominal interest rate risk on the balance sheet of the collective fund, which corresponds to the interest hedge of the IDC contract when aggregated across all generations. ${ }^{19}$

\section{CDC variation 1}

No recovery period: pension rights are immediately (one-to-one) adjusted with shocks on the balance sheet of the collective scheme.

\section{CDC variation 2}

Longer recovery period: 30-year recovery period (instead of 10-year).

\section{CDC variation 3}

Recovery contributions: contributions may be adjusted +/- 5\%-points during the recovery period (instead of fixed contribution rate).

Table 2 also provides the specification of three variations that differ from the benchmark design in a single aspect. The contract in variation 1 has no recovery period: pension rights are immediately (one-to-one) adjusted to shocks on the balance sheet of the collective scheme, not through a 10-

\footnotetext{
${ }^{19}$ According to the Dutch Central Bank, Dutch pension funds on average hedge $45 \%$ of the nominal interest rate risk on their balance sheets. See http://www.dnb.nl/en/news/news-and-archive/dnbulletin2013/dnb295970.jsp.
} 
year recovery period. The contract in variation 2 has a longer recovery period of 30 years (instead of 10 years in the benchmark contract). The contract in variation 3 features recovery contributions instead of a fixed contribution rate. Contributions may deviate up to $+/-5$ percentage points during the recovery period, in which case the contribution rate is temporarily higher or lower than the usual (actuarially fair) contribution rate.

\section{Results}

This section compares the allocation of financial risks in a number of pension contracts using the impulse-response analysis. We start with a special case in which the risk allocation in the IDC and CDC contracts is equal, namely in an IDC contract without life cycle investment profile and a CDC contract without recovery period. This common starting point clarifies which aspects of the IDC and CDC contracts are responsible for the different allocation of risk in more realistic IDC and CDC contracts. Subsequently, we introduce a life cycle investment strategy in the IDC scheme and a recovery period in the $\mathrm{CDC}$ scheme. This improves the allocation of stock market risk across agegroups in both IDC and CDC. Now, the risk allocations in IDC and CDC are not equivalent anymore. Subsequently, we consider other risk factors: interest rate risk and inflation risk.

\subsection{The allocation of equity risk}

\section{Starting point: no age differentiation in risk profiles in IDC and CDC}

The analysis starts with a comparison of two contracts without age differentiation in the risk profiles, namely IDC variation 1 (no life cycle investment profile) to CDC variation 1 (no recovery period). In this special case the risk distribution across generations in IDC and CDC contracts appears to be equivalent, see figure 2 .

Figure 2: Effect of equity shock on pension income in IDC without life cycle and CDC without recovery period

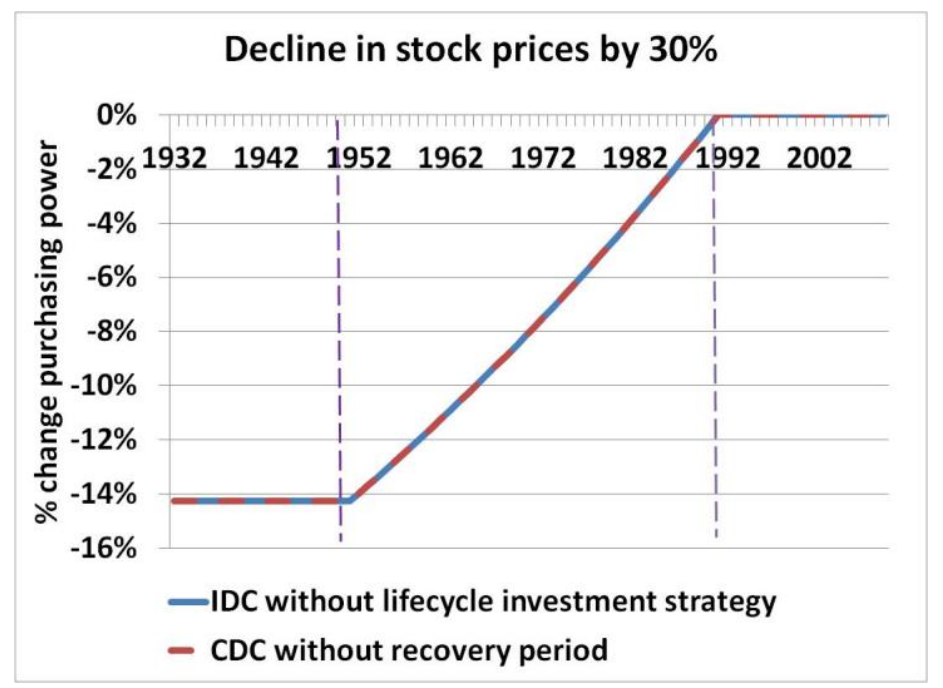

An equity shock affects all generations in both contracts equally in terms of accumulated pension wealth. In this example stock prices decline by 30 percent and the accumulated pension wealth of all generations is exposed for 49 percent to stock market risk, both in the IDC and in the CDC scheme. Note that the CDC scheme immediately (one-to-one) adjusts the annuities of participants in line with 
the assets on the balance sheet. Hence, all generations lose nearly 15 percent (49 percent exposure to a 30 percent decline) of accumulated pension wealth. For current retirees, born in 1950 or earlier, this simply implies that they lose 15 percent of their retirement consumption from their occupational pension income. For working generations, the consumption effect is smaller because only accumulated pension wealth is affected, while future pension accruals (i.e. future contributions) are unaffected. For young generations born in the 1980s, the accumulated pension wealth is relatively small so that their consumption shock is limited. For generations born in 1990 and afterwards there is no effect.

In both contracts the risk exposure of young generations in terms of consumption is small compared to the risk exposure of retired generations. Both contracts are far away from a first-best risk sharing solution, which would smooth shocks across as many generations as possible, so that each separate generation is affected as little as possible in terms of consumption (see e.g. Bovenberg and Mehlkopf, 2014). We explore how the risk distribution can be improved by introducing a life cycle investment strategy in the IDC scheme or a recovery period in the CDC scheme.

\section{Age differentiation in risk profiles in IDC and CDC}

The distribution of risk across generations in the IDC contract can be improved by adopting a life cycle investment strategy. Figure 3 shows that, without adjustment of the asset mix during the life cycle, the elderly face a much higher equity risk. A constant asset mix during the life cycle results in a higher consumption effect for retirees than for workers, because workers also have human capital which is (assumed to be) unaffected by the decline in stock prices.

Figure 3: Effect of equity shock on pension income in IDC contract with and without life cycle strategy

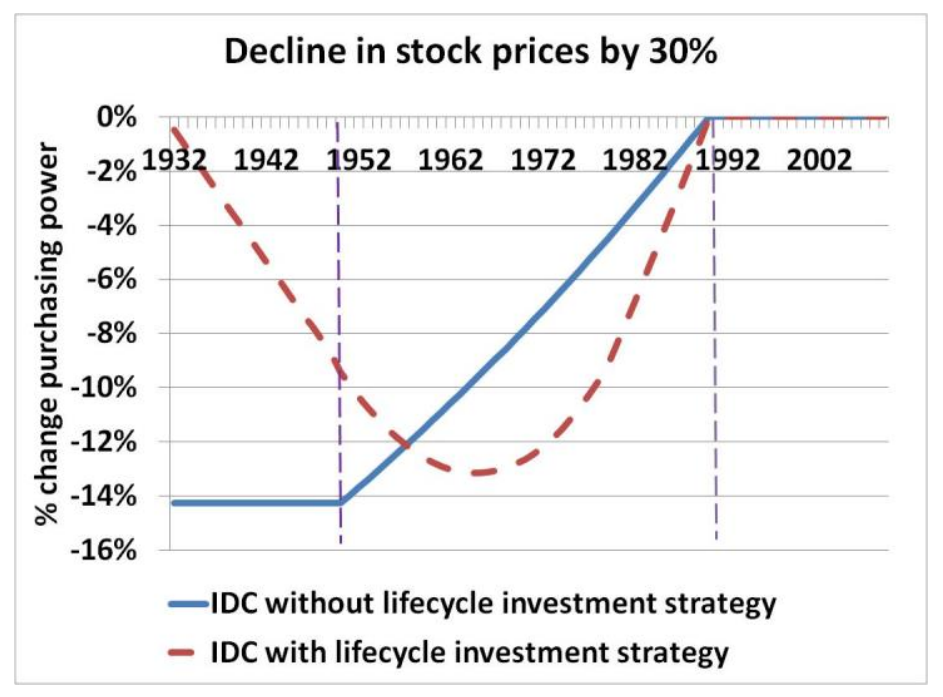

A life cycle portfolio strategy can reduce the exposure of elderly to equity risk. This improves welfare, if employees are more flexible then pensioners to adjust labor supply to absorb financial shocks. However, as discussed in section 2, the IDC life cycle has two limitations. First, the risk exposure of very young working generations born in the 1980s is small because of the borrowing constraint. These generations have a low risk exposure in terms of consumption. Even if their financial wealth is invested fully in stocks, their risk exposure in terms of consumption is rather low because these generations have accumulated very little financial wealth. Second, generations born 
in 1990 and later are not at all exposed to stock market risk, as they have not started to work yet. This is suboptimal in comparison to a first-best solution in which individuals are exposed to equity risk even before they are born to benefit from imperfect correlation of asset returns over time.

Figure 4: Effect of equity shock in CDC contract with and without recovery period on pension income

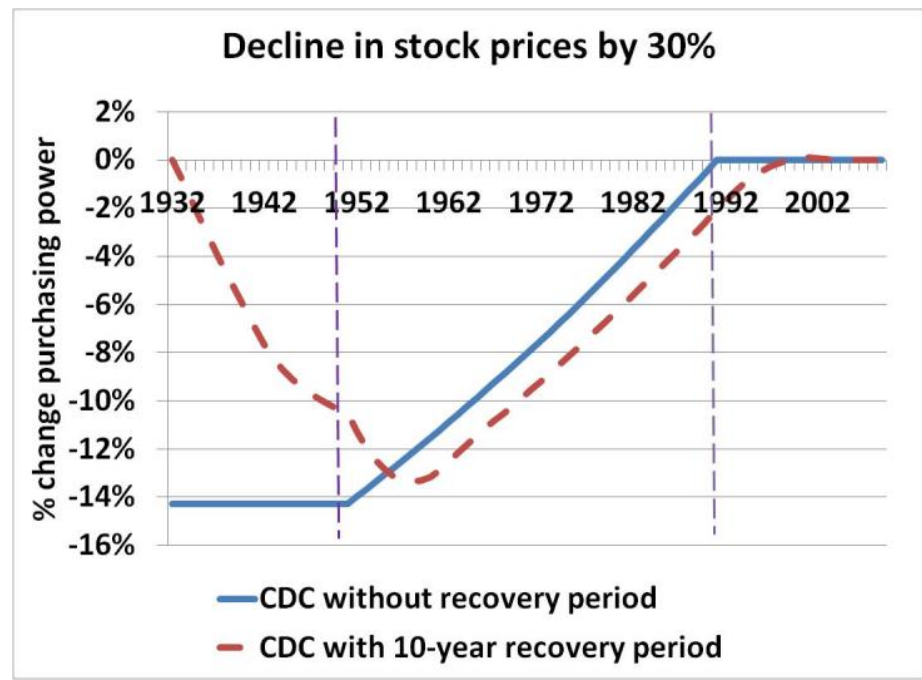

The allocation of risk across generations in the CDC contract can be improved by introduction of a recovery period. Figure 4 shows that, without the use of a recovery period, the elderly face a much higher equity risk. The introduction of a recovery period reduces the risk exposure of elderly generations, while increasing the risk exposure of younger generations, including those who will enter the scheme during the period in which the shock is absorbed.

Figure 5: Implicit fraction invested in stocks during life cycle due to 10-year recovery period in CDC

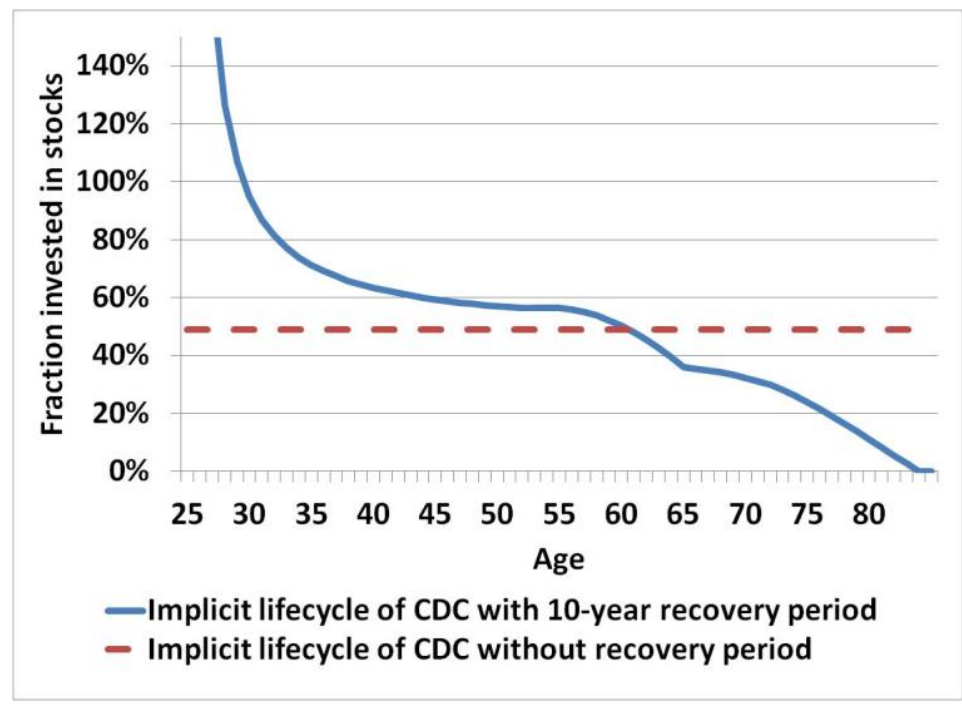

The impact of a recovery period can also be illustrated in terms of the implicit life cycle mix instead of consumption effects. The "implicit" life cycle asset allocation in the CDC contract with a 10-year recovery period is the asset mix in an IDC contract that yields exactly the same allocation of stock market risk across generations as the CDC contract. This implicit life cycle mix is illustrated in Figure 5. The introduction of a recovery period reduces the risk exposure of elderly generations, while 
increasing the risk exposure of younger generations. Generations older than 62 have an implicit exposure to stock market risk that is smaller than the risk exposure of the collective asset mix (49 percent), while generations younger than 62 have an implicit risk exposure that is larger than the collective mix. The termination of the accrual of pension rights results in a kink in the life cycle at retirement age.

\section{IDC versus CDC: traded risk factors}

Figure 6 combines the earlier results of figures 3 and 4 and compares the impact of an equity shock in an IDC and CDC contract on pension income. The figure shows that the CDC contract allocates some equity risk from the oldest generations to the youngest current generations and to generations born after 1990, entering the labor market in the near future. The redistribution effect is relatively small - only a small portion of the risks borne by pensioners is redistributed to young and future generations - since the collective contract applies a 10-year recovery period. In both the individual and the collective contract, a large part of the equity risk is borne by the generations who are near retirement and have accumulated a relatively large amount of pension wealth. As expected, the $\mathrm{CDC}$ contract is able to reallocate current financial market risk to the very young (borrowingconstrained) and future generations, but the effect is small. The fraction of the aggregate loss that can be allocated to the (very) young and future workers is just 4 percent, see also appendix $B$. The intuition behind this result is that the share of the ten youngest generations in the assets and the liabilities of the pension fund is relatively small, so the fraction of risk that can be shifted onto these young generations is rather limited. In fact, Figure 6 demonstrates that the IDC scheme, by using a life cycle investment strategy, can largely replicate the allocation of traded risks across generations of the CDC scheme. Appendix B provides a sensitivity analysis of Figure 6.

Figure 6: Effect of equity shock in IDC and CDC scheme on pension income

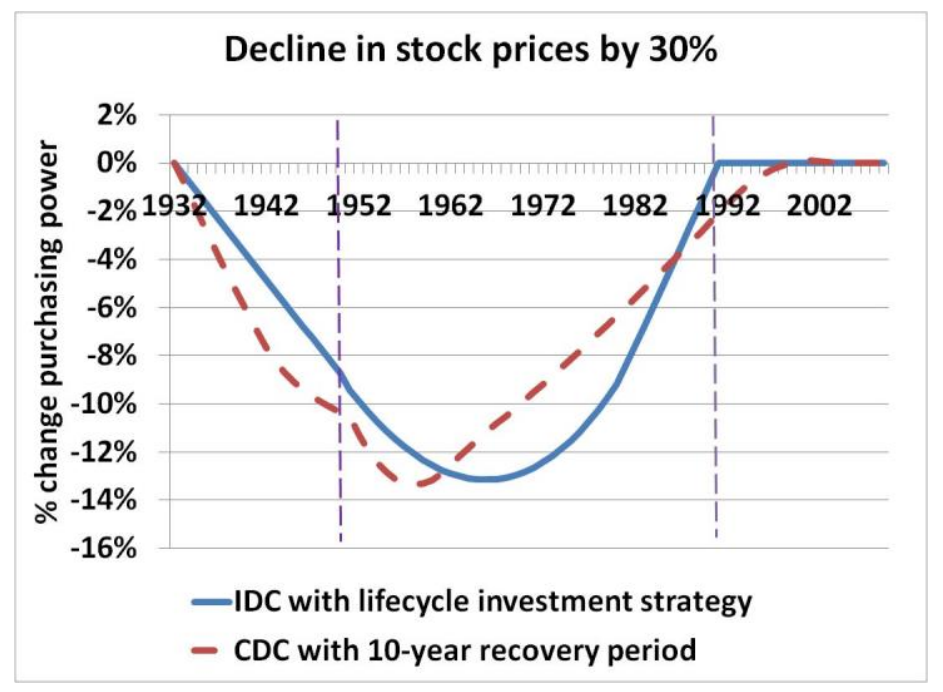

The difference between IDC and CDC contracts can be illustrated by the impact on consumption by year of birth, but also by the (implicit or explicit) life cycle investment strategy by age. The results for old (young) people are on the left (right) in figure 6, but vice versa in figure 7. The individual contract cannot match two aspects of the implicit life cycle mix of the collective contract. Firstly, the implicit 
exposure to stock market risk may go to infinity at the beginning of the working period. It is typically hard to replicate these exposures due to borrowing constraints (although stock options could help to alleviate this constraint). Secondly, the collective contract also exposes future participants (ages under 25 ) to stock market risk by using a smoothing period, while this is not possible in an individual contract.

Figure 7: Fraction invested in stocks in CDC with 10-year recovery period and in IDC with life cycle

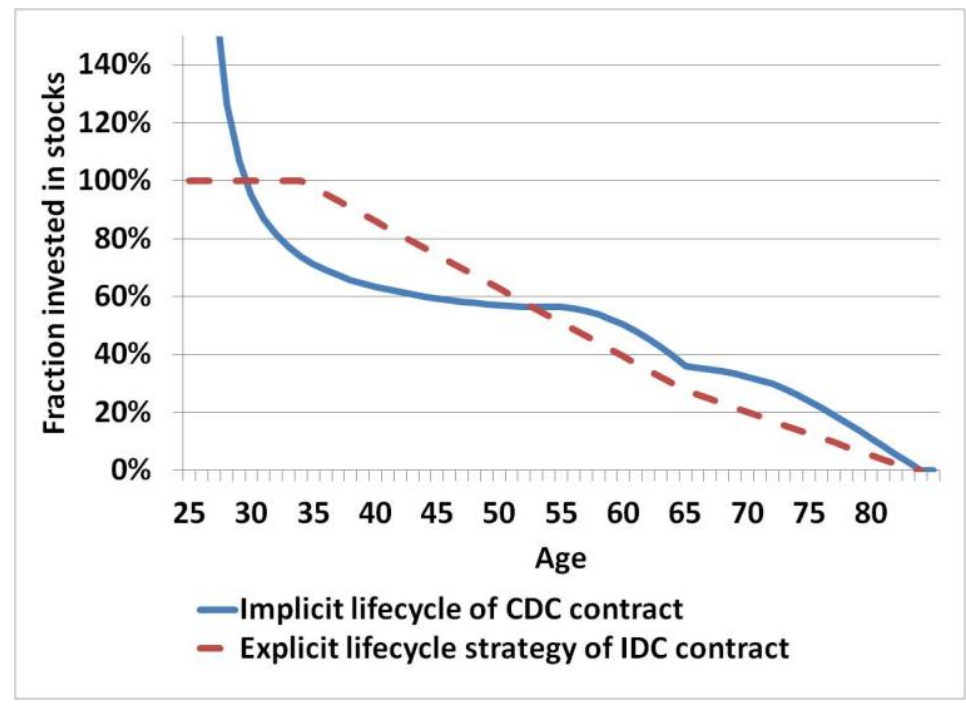

Figure 8: Effect of equity shock in CDC scheme with 10 or 30-years smoothing period

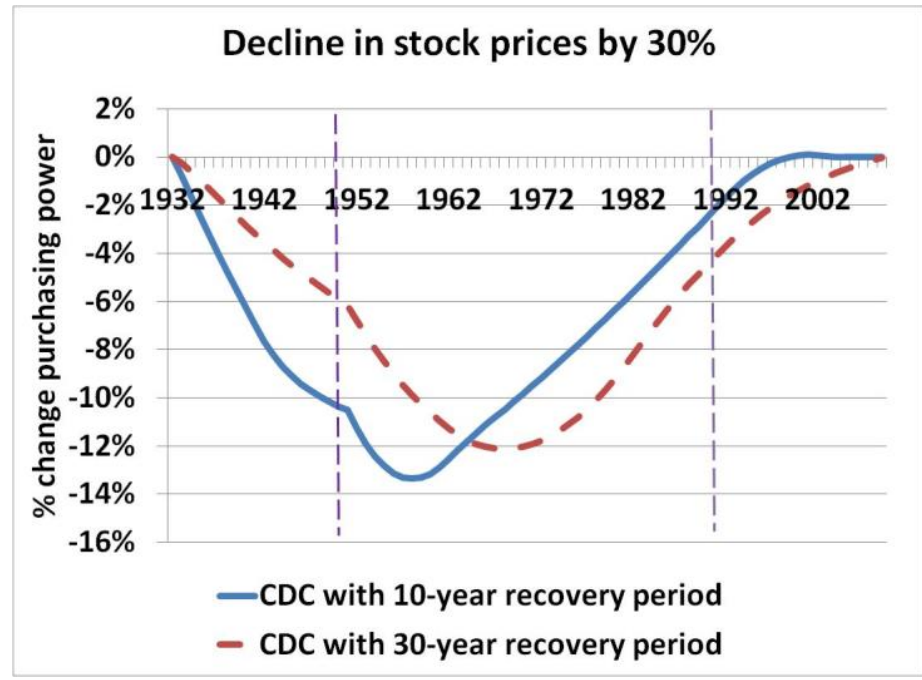

More risk can be reallocated from the elderly to young workers and future generations by lengthening the recovery period in a collective contract from 10 to 30 years (Figure 8). Alternatively, the pension contributions can be adjusted after a shock to enhance recovery of the financial position of the fund (Figure 9). ${ }^{20}$ Hence, the recovery period and the contribution rate are able to shift more of the current financial risk to future generations. In practice, however, large funding shortfalls may

\footnotetext{
${ }^{20}$ The adjustment of pension contributions is limited to 5 percentage points of the wage upward or downward, depending on the sign of the shock. If that is not enough, pensions are cut or increased.
} 
introduce discontinuity risks, as future participants may be unwilling to enter a pension fund if they face low indexation during a lengthy recovery period or contribution rates that exceed actuarially fair rates. ${ }^{21}$ Discontinuity risk is the main motivation for the relatively short maximum of ten years for the recovery periods of CDC contracts in Dutch pension legislation.

Figure 9: Effect of equity shock in CDC contract with and without contributions as recovery instrument

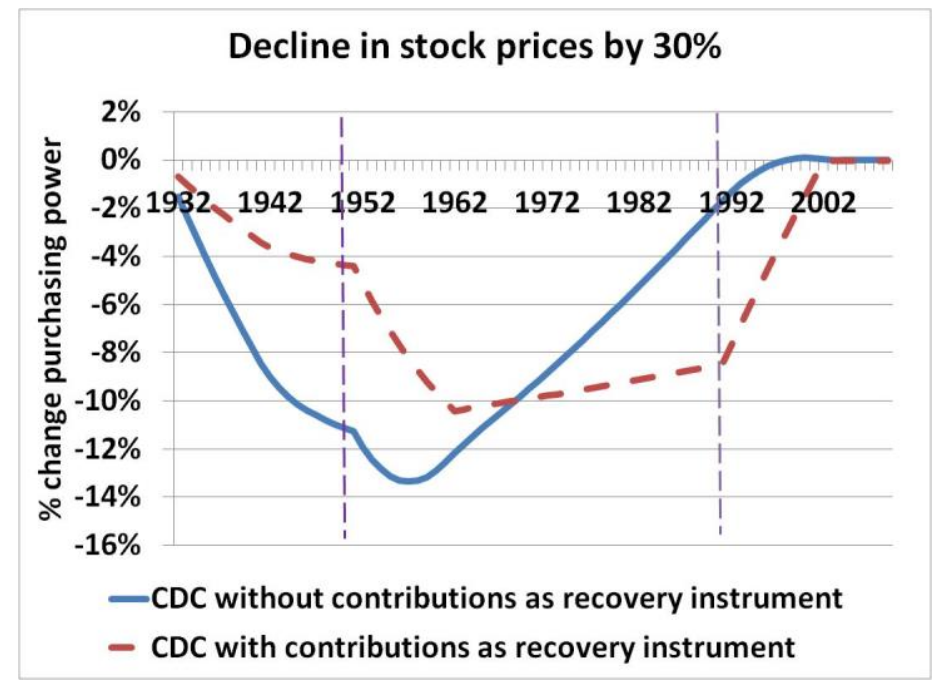

\subsection{The allocation of interest risk and inflation risk}

Now we move towards other risk factors in our model: interest rate risk and inflation risk. For interest rate risk and inflation risk, the desired lifecycle pattern is less clear than for equity risk. For example, in our incomplete market setting nominal bonds protect the investor against interest rate risk, but at the same time expose him to inflation risk.

Figure 10: Effect of permanent (both nominal and real) interest rate shock in IDC and CDC contract

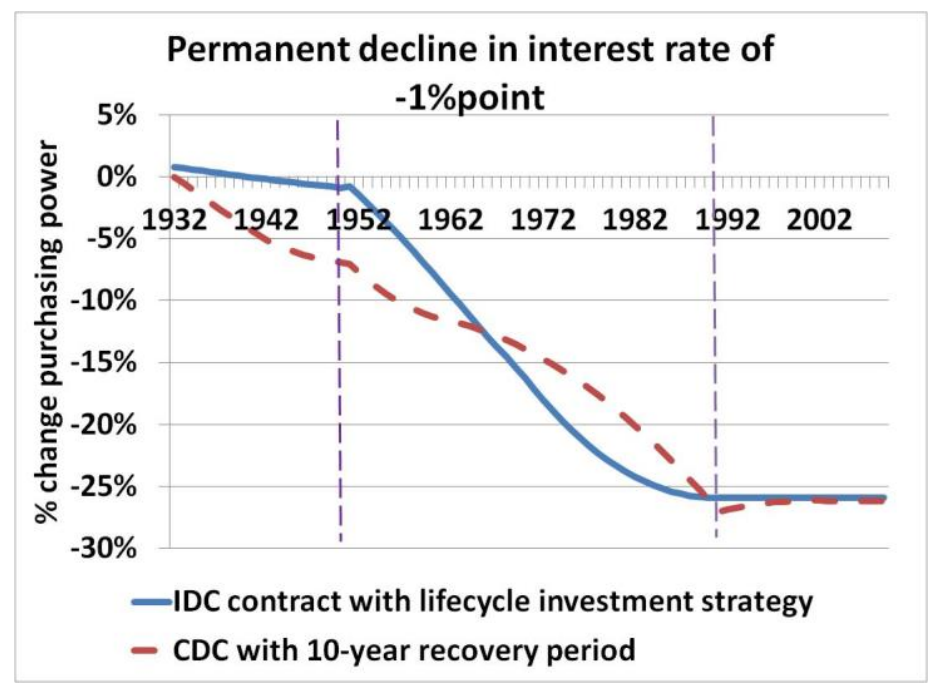

\footnotetext{
${ }^{21}$ In addition, these instruments may introduce labor market distortions.
} 
Therefore, in the remaining analysis of this section we do not claim to know what the risk allocation across age-groups should look like. Instead, we measure quantitatively the risk distribution in typical IDC and CDC contracts and show the differences between the two contracts.

Figure 10 demonstrates the effect of a permanent shock in interest rates in both the IDC and CDC benchmark contracts. In both contracts future workers experience the full impact of a lower interest rate. In the IDC contract pensioners are partially hedged against interest rate risk, as the duration of their bonds corresponds to the duration of their liabilities. In the CDC contract the decline in the interest rate reduces the solvency of the pension fund to the extent that the interest risk is not hedged. The solvency rate determines future indexation.

Figure 11: Interest duration of assets in CDC and IDC schemes and of liabilities

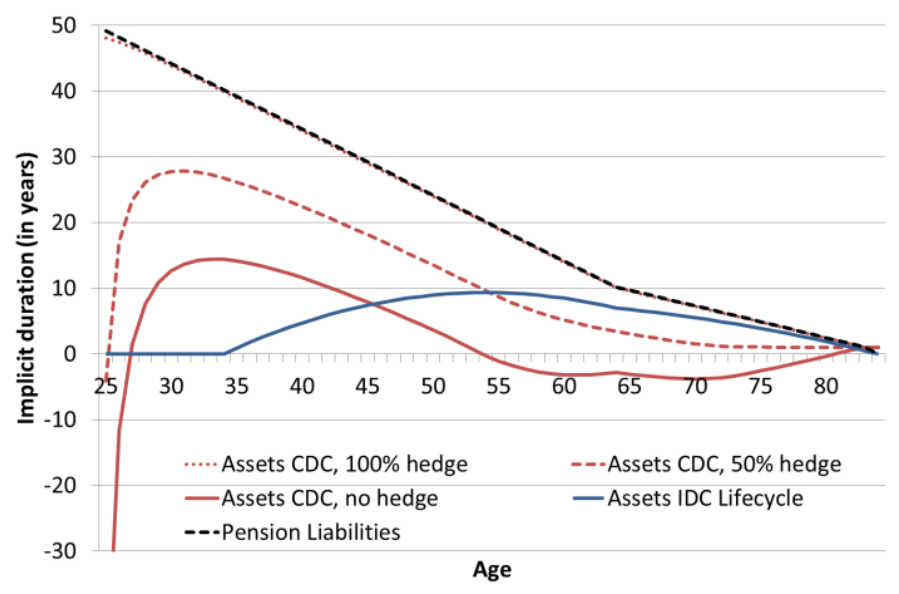

For equity risk, we can illustrate the exposure by calculating the implicit and explicit asset mix for different cohorts. For interest rate risk, we express the sensitivity of accumulated financial wealth to interest rate risk in terms of its duration. Figure 11 shows the implicit duration of the assets of a CDC scheme for different hedges of the interest risk. In addition, it shows the duration of assets during the IDC lifecycle (Table 1) and the duration of the pension liabilities. The difference in duration, measured by the vertical distance at each age, measures the exposure to interest risk. In the CDC scheme that fully hedges its pension liabilities, the implicit duration of the assets equals the duration of the liabilities at each age. The participants are not exposed to interest risk, as the solvency rate is insensitive to changes in interest rates.

Young employees have a high exposure to interest risk in an IDC scheme, as they invest (nearly) all their capital in equity. Old employees and retirees can reduce their exposure to interest risk by investing in bonds with an appropriate duration. In the IDC contract in this paper the duration of the bonds is equal to the remaining life expectancy, so the unhedged interest risk is quite small. The CDC contract has more options to hedge the interest risk of young employees, but less flexibility in choosing a specific interest hedge at a specific age. In the CDC contract, the interest hedge at fund level and the recovery period determine the exposure to interest risk at different ages.

Figures 10 and 11 do not give a decisive answer about the optimality of the exposure to interest risk at different ages in the IDC and CDC scheme. This should be addressed in future research. 


\section{IDC versus CDC: non-traded risk factors}

In Figure 12 we compare the effects of an inflation shock in an individual contract with life cycle asset mix and a collective contract with a uniform asset mix and a 10 -year recovery period. The individual contract results in a high share of nominal bonds at the end of the life cycle and does not protect against inflation. The collective contract intends to compensate for higher prices. The lower solvency rate of the fund reduces future indexation.

Figure 12: Effect of unexpected higher price level in IDC and CDC scheme

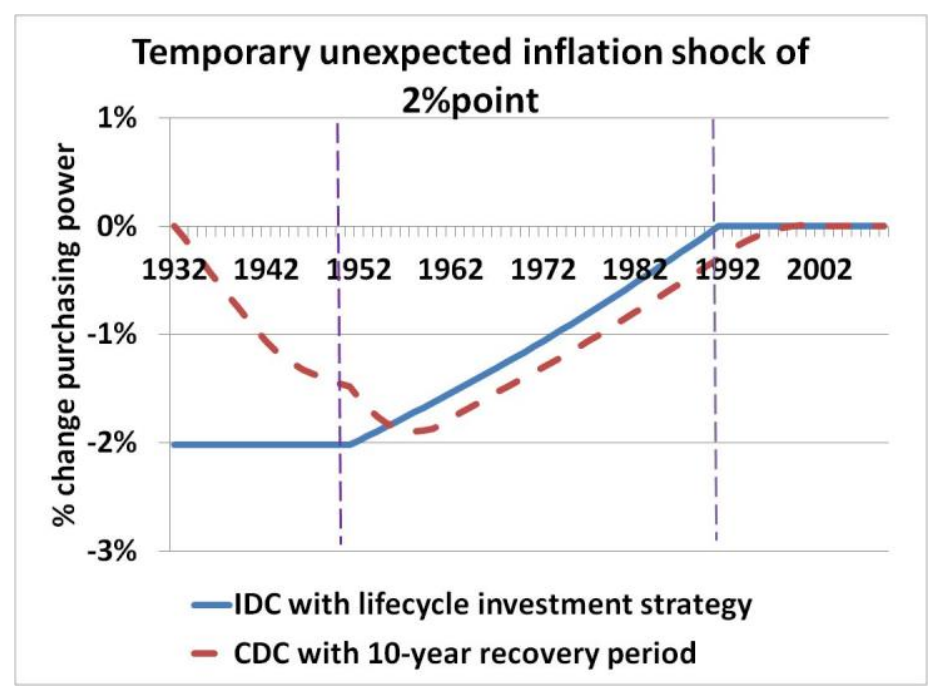

A CDC contract with cost-of-living adjustment reallocates inflation risk from the eldest generations to working generations and to generations that enter the labor market in the near future. However, the retirees are only partially protected for inflation risk. The compensation for the unexpected shock in the price level reduces the solvency rate of the fund. By reducing indexation during the recovery period the solvency rate increases again. Younger retirees, who will outlive the 10-year recovery period, therefore face a larger consumption effect than older retirees, who may not outlive the ten years.

Hence, the collective pension fund is able to offer retirees (partial) protection against a temporary inflation shock, which we assume to be unavailable in the financial market. For all retired generations together we can see in Figure 12 that the exposure to inflation risk is roughly halved, somewhat more for older retirees, somewhat less for younger retirees. The other half of the inflation risk of the elderly is reallocated to working participants. The reallocation of inflation risk from old to young can be welfare-improving if the young are better able to bear inflation risk than the old. This may be the case because the young have human capital, which is linked to wageinflation and therefore correlates with price-inflation. Moreover, the young have a longer horizon to retirement and may use their labor supply and consumption behavior strategically as a buffer against inflation risk. Retirees have little or no human capital left and may lack the flexibility of the young to deal with inflation shocks as a result of habit formation. ${ }^{22}$

\footnotetext{
${ }^{22}$ The size of the welfare gain associated with an internal inflation-risk swap between young and old within a collective pension fund can be substantial. Campbell and Viceira (2001) report that the certainty-equivalent wealth effect of access to inflation-indexed bonds can be as large as $10-30 \%$.
} 
Figure 13: Effect of permanent inflation shock in IDC and CDC scheme, CDC uses real interest rate as discount factor

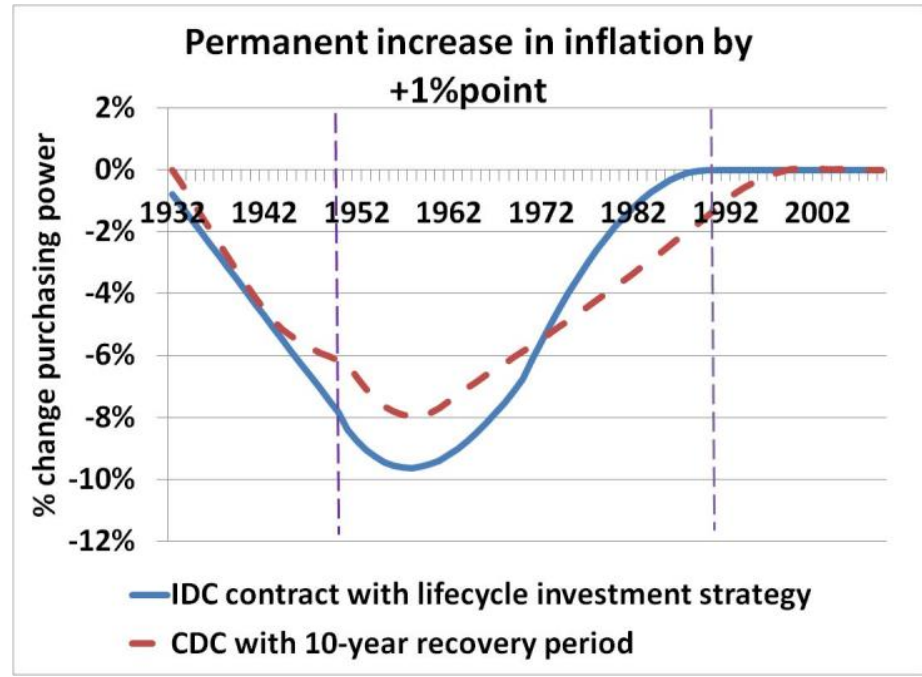

Figure 13 demonstrates the effect of a permanent increase in inflation and inflation expectations in both the IDC and CDC benchmark contracts. It is assumed that the increase in inflation leads to an increase in nominal interest rates, while leaving real interest rates unaffected. The increase in inflation reduces the value of bonds held by the fund, but does not affect future real returns on investment. In the collective contract the liabilities are unaffected if the fund uses the real interest rate as discount factor, but the solvency of the fund decreases due to the lower value of bonds. This reduces future indexation. In the individual contract young and future participants are unaffected, as they hold no nominal bonds.

Figure 13a: Effect of permanent inflation shock in IDC and CDC scheme, CDC uses nominal interest rate as discount factor

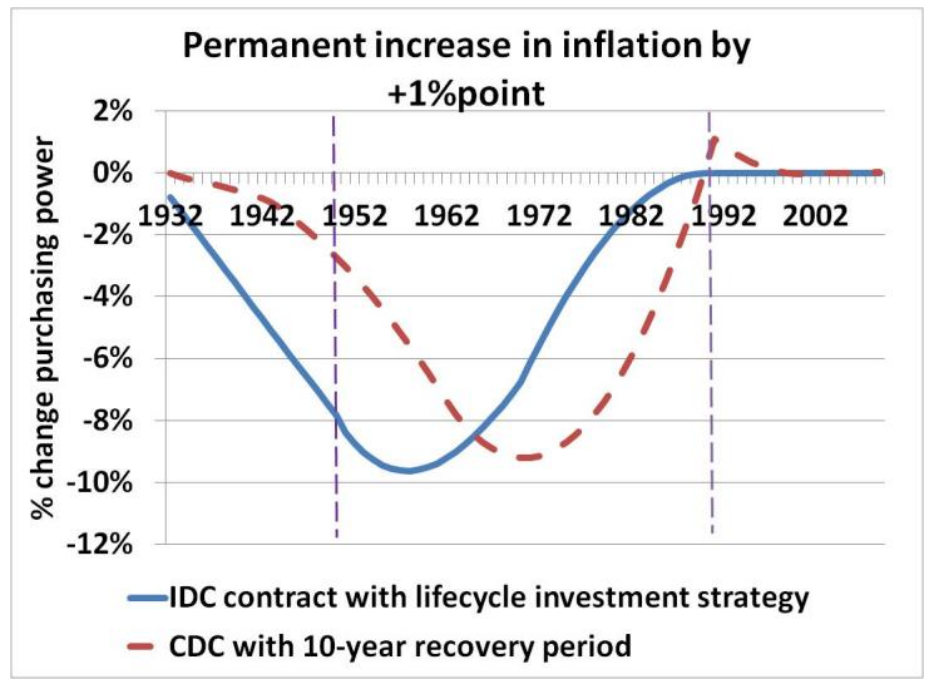

Figure 13a shows the same comparison as Figure 13, but now the CDC contract is designed on the basis of a nominal funding ratio (i.e. a discount rate) instead of a real one. We assume that the real interest rate is unaffected, so the nominal interest rate increases as well. This collective contract 
provides pensioners more protection against inflation. The solvency of the fund increases due to the lower discounted value of nominal liabilities and increases indexation.

\section{Conclusions}

The impulse-response analysis in this paper illustrates that collective contracts allow for sharing equity risk with future generations and lift the borrowing constraint for young generations. The impact of intergenerational risk sharing on the allocation of risks depends on the length of the smoothing period and the availability of contributions as a steering mechanism. In real-world contracts the smoothing period is typically short (up to ten years in the current Dutch institutional setting) in order to reduce discontinuity risk. The potential to use contributions as a steering mechanism is limited, as contributions are small relative to the pension liabilities. Individual contracts can largely mimic the equity risk allocation of collective contracts with a life cycle asset allocation, though not fully. They are unable to share risks with future generations and to lift the borrowing constraint for younger generations.

In individual contracts using a life cycle young employees have a high exposure to interest risk, if they invest in equity only. Collective contracts provide young employees some hedge to interest risk, but are less flexible to choose a specific hedge during the life cycle, as it is determined by the interest hedge at fund level and the speed of the recovery process after a shock. In order to protect the elderly, the pension fund has to hedge the (downside) interest risk to a large extent.

Collective contracts are potentially able to share non-traded risk factors, such as inflation risk, more effectively than individual contracts. The current collective contracts, using nominal instead of real interest rates, can share temporary inflation shocks, but are not well-equipped to deal with permanent inflation shocks. As the inflation risk premium is not observed, it is somewhat arbitrary how young participants should be rewarded for bearing the inflation risk of older participants. Only if inflation risk becomes tradable, for example as a result of the issuance of inflation-linked bonds by governments, individual contracts can provide similar protection.

\section{Literature}

Allen, F. and D. Gale, 1997, Financial markets, intermediaries, and intertemporal smoothing, Journal Political Economy, 105, pp. 523-45.

Ang, A. and G. Bekaert (2007), Stock return predictability: Is it there? Review of Financial Studies, 20, pp. 651-707.

Arrow, K.J. and G. Debreu (1954), Existence of an equilibrium for a competitive economy, Econometrica, 22, pp. 265-290.

Barclays (2012), Global Inflation-Linked Products: A User's Guide, Inflation-Linked Research.

Ball, L. and N. Mankiw (2007), Intergenerational risk sharing in the spirit of Arrow, Debreu and Rawls, with applications to social security design, Journal of Political Economy, 115, pp. 523-547. 
Beetsma, R.M.W.J. and A.L. Bovenberg, Pensions, Intergenerational Risk Sharing and Inflation, Economica, 76, pp. 364-386.

Benzoni, L., P. Collin-Dufresne and R.S. Goldstein (2007), Portfolio Choice over the Life-Cycle when Stock and Labor Markets are Cointegrated, The Journal of Finance, 62, pp. 2123-2167.

Blake, D., D. Wright and Y. Zhang (2014), Age-dependent investing: Optimal funding and investment strategies in defined contribution plans when members are rational life cycle financial planners, Journal of Economic Dynamics \& Control, 38, pp. 105-124.

Bodie, Z., R.C. Merton and W.F. Samuelson (1992), Labor Supply Flexibility and Portfolio Choice in a Life Cycle Model, Journal of Economic Dynamics and Control, 16, pp. 427-449.

Boelaars, I., L. Bovenberg, J. de Haan, S. van Hoogdalem, T. Kocken, M. Lever, R. Mehlkopf, Th. Nijman and E. Ponds (2014), Gedeelde standpunten over de toegevoegde waarde van risicodeling met toekomstige generaties, October 2014, www.netspar.nl.

Bohn H. (2006), Who Bears What Risk? An Intergenerational Perspective. In: D. Blitzstein, O, Mitchell and S.P. Utkus (eds), Restructuring Retirement Risks, Oxford University Press.

Bohn H. (2009), Intergenerational Risk Sharing and Fiscal Policy, Journal of Monetary Economics, 56, pp. 805-816.

Bohn H. (2012), Private versus public risk sharing: Should governments provide reinsurance? In: A.L. Bovenberg, C. van Ewijk and E. Westerhout (eds.),The Future of Multi-Pillar Pensions, pp. 187-224. Cambridge, UK: Cambridge Univ. Press, 421 pp.

Bouwman, K. and Th. Kocken (2014), Marktrisico-delend versus individueel pensioen, Replicatie van een collectief FTK pensioen, Discussion Paper, www.netspar.nl.

Bovenberg, L., R. Koijen, T. Nijman and C. Teulings (2007), Saving and investing over the life cycle and the role of collective pension funds, Economist - Netherlands, 155(4), pp. 347-415.

Bovenberg, A.L. and R.J. Mehlkopf (2014), Optimal Design and Regulation of Funded Pension Schemes, Annual Review of Economics, vol. 6, pp. 445-74.

Bovenberg, A.L., R.J. Mehlkopf and Th. E. Nijman (2014), The Promise of DA Plans: Lessons for the United States, forthcoming in: Mitchell, O. (ed.): Reimagining Pensions, the next 40 years, Oxford University Press. Available as Netspar Occasional Paper: http://arno.uvt.nl/show.cgi?fid=133819.

Bovenberg, A.L., R.J. Mehlkopf and S. van Bilsen (2014), Variable Annuities in Pension Schemes with Risk Sharing, Valuation, Investment and Communication, Netspar discussion paper.

Bovenberg, A.L., Th. E. Nijman and B.J.M Werker (2012), Voorwaardelijke pensioenaanspraken: over waarderen, beschermen, communiceren en beleggen, Netspar Occasional Paper, 2 April (in Dutch).

Campbell, J.Y. and Y. Nosbusch (2007), Intergenerational risk sharing and equilibrium asset prices, Journal of Monetary Economy, 54, pp. 2251-68. 
Campbell, J.Y. and L. Viceira (2001), Who should buy long-term bonds? American Economic Review, 91, pp. 99-127.

Chen, Z., J. de Haan and E. Ponds (2014), Beter pensioen bij breder draagvlak, October, www.netspar.nl.

Cochrane, J. (2008), The dog that did not bark: A defense of return predictability, Review of Financial Studies, 21, pp. 1533-75.

Cocco, J.F., F.J. Gomes and, P.J. Maenhout (2005), Consumption and portfolio choice over the lifecycle, The Review of Financial Studies, 18(2), pp. 491-533.

Constantinides, G.M., J.B. Donaldson and R. Mehra, (2002). Junior can't borrow: a new perspective on the equity premium puzzle, Quarterly Journal of Economics, 117, pp. 269-96.

Cui, J., F. de Jong and E. Ponds (2011), Intergenerational risk sharing within funded pension schemes, Journal of Pension Economics and Finance, 10, pp. 1-29.

Department for Work \& Pensions (2013), Reshaping workplace pensions for future generations, Public consultation, DWP, London.

Diamond, P. (1977), A framework for social security analysis, Journal of Public Economics, 8, pp. 27598.

Gollier, C. (2008), Intergenerational risk sharing and risk taking in a pension fund, Journal of Public Economics, 92, pp. 1463-1485.

Gordon, R.H. and H.R. Varian (1988), Intergenerational risk sharing, Journal of Public Economics, 37, pp. 185-202.

Goyal, A. and I. Welch, (2008), A comprehensive look at the empirical performance of equity premium prediction, Review of Financial Studies, 21, pp. 1455-508.

Lever, M.H.C., R.J. Mehlkopf and C. van Ewijk (2012), Generatie-effecten pensioenakkoord, CPB Notitie, 30 May (in Dutch).

Lever, M.H.C. and T.O Michielsen (2015), Risk sharing in individual and collective defined contribution pensions: Modest benefits from collective risk sharing, CPB, The Hague.

Merton, R.C. (1983), On the role of social security as a means for efficient risk sharing in an economy where human capital is not tradable. In: Z. Bodie and J. Shoven (eds.), Financial Aspects of the United States Pension System, pp. 325-58, Chicago: Univ. Chicago Press.

Novy-Marx, R. and J. Rauh (2012), Linking Benefits to Investment Performance in US Public Pension Systems, NBER Working Paper No. 18491.

Queen's speech (2014), Queen's speech during the state opening of parliament, https://www.gov.uk/government/publications/queens-speech-2014-what-it-means-for-you/queensspeech-2014-what-it-means-for-you\#private-pensions-bill. 
Shiller, R. (1999), Social Security and Intergenerational Risk Sharing, Carnegie-Rochester Series in Public Policy, June, 50 (99), pp. 165-204.

Shiller, R. (2003), Social Security and Individual Accounts as Elements of Overall Risk-Sharing, American Economic Review, 93(2).

Smetters, K. (2006), Risk sharing across generations without publicly owned equity, Journal of Monetary Economy, 53, pp. 1493-508.

Teulings, C.N. and C.G. de Vries (2006), Generational Accounting, Solidarity and Pension Losses, De Economist, 154, pp. 63-83.

Westerhout, E.W.M.T., J.P.M. Bonenkamp and D.P. Broer (2014), Collective versus Individual Pension Schemes: A Welfare-Theoretical Perspective, CPB Discussion Paper, www.cpb.nl.

\section{Appendix A: Dutch Occupational Pension Contracts}

The CDC pension contract used in the impulse-response analysis of this paper is based on occupational pension schemes in the Dutch second pillar. ${ }^{23}$ These occupational pension schemes are funded, and the value of total assets currently amounts more than 1 trillion Euro, or $160 \%$ of Dutch GDP. ${ }^{24}$ Dutch pension funds are organized as independent trusts with their own governance and administrative structures. The governing board of a pension fund traditionally consists of employer and employee representatives, although more recently also retiree representatives and independent specialists can become board members. These representatives act as fiduciary trustees.

The Netherlands have traditionally been home to collective, DB-like pension contracts, albeit without the explicit sponsor guarantees that are common in some other countries, like the UK. The vast majority of Dutch employees participate in sector-wide and professional group pension funds without sponsor guarantees. ${ }^{25}$

At present, the pension contracts generally do not include outside guarantees anymore ${ }^{26}$, and contribution levels are largely stabilized. The Dutch pension contracts have therefore become 'collective defined contribution' (CDC) schemes: collective pension contracts without guarantor-oflast-resort, and with (more or less) stable contributions, in which adjustments to the level of entitlements are a primary steering variable to absorb financial shocks on the collective balance sheet of the pension scheme.

\footnotetext{
${ }^{23}$ Our description is descriptive in nature and covers the main economic aspects of Dutch pension contracts, while abstracting from institutional details. Bovenberg, Mehlkopf and Nijman (2014) discuss recent developments and the current status of pension reform in the Netherlands. Bovenberg, Mehlkopf and Van Bilsen (2014) formalize CDC schemes, including the market valuation of the variable annuities provided by these schemes.

${ }^{24}$ Ssee www.statistics.dnb.nl.

${ }^{25}$ Sector-wide pension funds cover by far the highest proportion of employees; around $88 \%$ of Dutch employees that are member of an occupational pension fund participate in a sector-wide fund. Professional funds represent, at 1\%, a minor proportion of employees. All figures are as per 16 September 2013; see www.statistics.dnb.nl.

${ }^{26}$ With the exception of some company pension funds.
} 
Nevertheless, the CDC contracts still have some features that are similar to DB schemes. For instance, the CDC contracts still provide (deferred) annuities to participants that target a defined lifetime income stream during retirement, calculated on the basis of years of service and a reference wage. The reference wage used to be the final salary, but in the last decade most funds have moved to career-average schemes. Dutch collective schemes typically target an annuitized pension benefit of about $75 \%$ of average pay (including the public pension) after 40 years of service. The schemes moreover have the ambition to revalue these annuities to the development of prices or contractual wages.

The solvency regulation for Dutch occupational pension funds is laid down in the Financial Assessment Framework (Financieel Toetsingskader, or FTK), which is currently in the process of being amended. The situation described here, and used in the modelling of the CDC contract in this paper, is largely based on the new FTK that is in force from 1 January 2015. According to these solvency rules, Dutch pension contracts need to adhere to a maximum recovery period of ten years for financial shocks. During the recovery period, pension funds adjust the level of annuity units of participants gradually, in annual steps. If the funding ratio (total assets divided by liabilities) is low, a pension fund gradually reduces the value of the annuity units of participants so that the financial position of the fund gradually recovers. Similarly, the value of the annuity units gradually increases if the funding ratio is high. Since the maximum recovery period is equal to ten years, a pension fund is able to recover from a funding deficit of 10 percent by annually reducing the level of pension annuities of participants by 1 percent during the 10-year recovery period. ${ }^{27}$ The 10 -year recovery period thus allows Dutch collective pension schemes to use their financial buffer to smooth the impact of (financial) shocks over time, by sharing the impact of the shock with current and future participants of the contract, up until those generations that enter the scheme in ten years' time.

\section{Appendix B: Robustness check for asymptotic recovery mechanism}

This Appendix explores the case in which the 10-year recovery period is implemented asymptotically. By this we mean that a shock is not recouped within a 10 -year period, but is recouped in such a way that every year $1 / 10^{\text {th }}$ of the remaining funding deficit or surplus is corrected, as depicted in Figure 14 below. In the new Dutch Financial Assessment Framework for occupational pension funds (as described in Appendix A), funding deficits or surpluses will be dealt with according to this mechanism. For the sake of simplicity, in the modelling of the CDC contract in this paper, every year one tenth of the remaining deficit or surplus is recouped.

Figure 14. Default recovery process and asymptotic recovery process for the situation in which there is a one-time shock to the funding ratio in the year 2015.

\footnotetext{
${ }^{27}$ The recovery period in CDC schemes has similarities with a 'return smoothing' mechanism that is observed in some countries.
} 


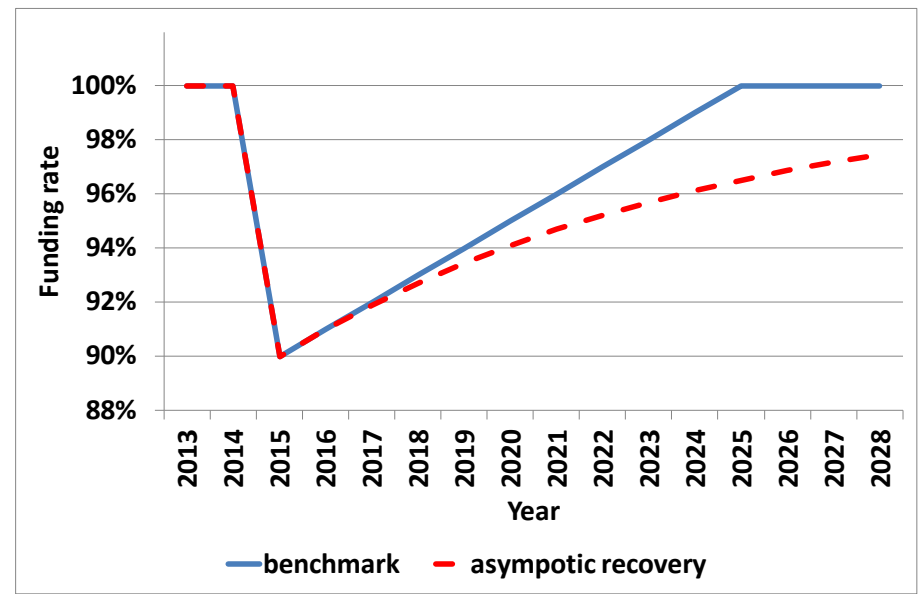

Figure 15 below is the same as Figure 6 but now the recovery period is asymptotic.

Figure 15. Effect of equity shock on pension income in IDC and CDC scheme (as in Figure 6), with asymptotic recovery period.

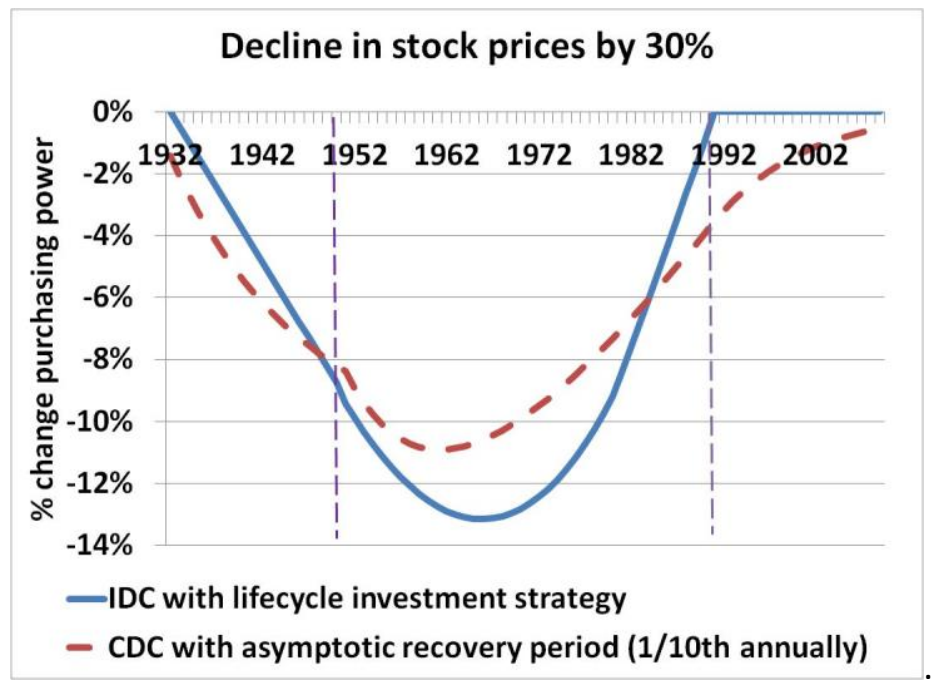

Figure 15 above shows that an asymptotic recovery period allows the pension fund to allocate a larger fraction of current risk to young and future participants (compare to Figure 6). For example, the cohort born in 1990 (which enters the fund at the moment the shock occurs) now loses $4 \%$ in the $\mathrm{CDC}$ contract while this was only $2 \%$ in Figure 6 . Hence, the consumption effect of future generations roughly doubles when using an asymptotic recovery period. In the case of asymptotic recovery, future generations bear $4 \%$ of a current shock and very young (borrowing constrained) generations bear an additional $3 \%$. So in total, $7 \%$ of a current shock can be allocated to future and very young generations, whereas this was $3 \%$ in the default setting of figure 6 .

Figure 16 shows the implicit lifecycle pattern of the CDC contract with an asymptotic recovery mechanism. It follows from a comparison to Figure 7 that the implicit age-differentiation is now larger compared to the default mechanism: the exposure to stock market risk of young participants is increased, while the exposure of older participants is reduced. 
Figure 16. Implicit fraction invested in stocks in CDC with 10-year recovery period and explicit fraction in stocks during life cycle in IDC (as in Figure 7), with asymptotic recovery period.

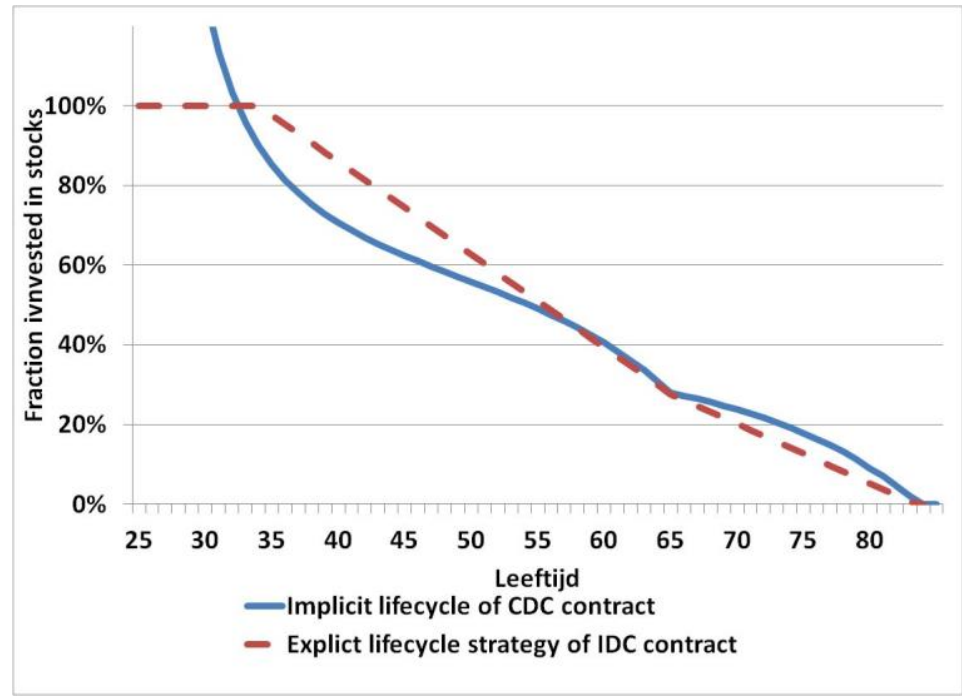



Publisher:

CPB Netherlands Bureau for Economic Policy Analysis

P.O. Box 80510 | 2508 GM The Hague

$\mathrm{T}$ (070) 3383380

December 2015 | ISBN 978-90-5833-710-8 